Buca Eğitim Fakültesi Dergisi, 2021, Say1 51, s. 287-303

Derleme Makalesi
The Journal of Buca Faculty of

Education, 2021, Issue 51, p.287-303

Review Article

\title{
Oyun Terapisi ve Oyun Terapisinin Gruplarda Kullanımı
}

\author{
Play Therapy and Use of Play Therapy in Groups
}

\author{
Semra KIYE ${ }^{l,}$, Ilhan YALÇIN ${ }^{2}$
}

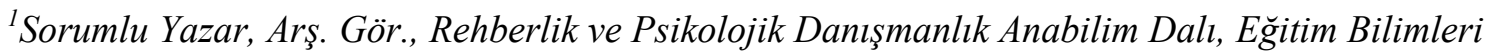
Fakültesi, Ankara Üniversitesi, Türkiye, skiye@ankara.edu.tr, (https://orcid.org/0000-00034414-5765)

${ }^{2}$ Doç.Dr.,Rehberlik ve Psikolojik Danışmanlık Anabilim Dalı,Eğitim Bilimleri Fakültesi, Ankara Üniversitesi, Türkiye, yalcini@ankara.edu.tr, (https://orcid.org/0000-0002-6407-9606)

Geliş Tarihi: 04.12.2020

Kabul Tarihi: 25.03 .2021

\section{ÖZ}

Oyun terapisi yaklaşık yüz yıllık bir geçmişe sahiptir ve çocuklarla psikolojik danışma yapmanın bir yoludur. Oyun terapisinde çocuklar doğal dilleri olan oyunu kullanarak kendilerini ifade ederler. Ayrıca yaşadıkları problemleri oyun oynayarak canlandırır ve böylelikle tarif edemedikleri duygularını keşfederler. Oyun terapisine ilişkin pek çok farklı kuramsal yaklaşım bulunmaktadır. Bununla birlikte oyun terapisi uygulamaları temelde direktif olan, direktif olmayan ve aile oyun terapileri olarak üç başlık altında toplanabilir. Günümüzde bireysel ve aile ile uygulanan oyun terapilerinin yanı sıra grupla uygulanan oyun terapileri de yaygınlaşmaya başlamıştır. Yapılan alanyazın incelemesinde yurt dışında grupla oyun terapisine ilişkin pek çok araştırma bulunurken Türkiye'de sınırlı sayıda araştırma bulunduğu anlaşılmaktadır. Bu çalışmanın amacı oyun terapisini ve oyun terapisinin gruplarda uygulanmasını ele almak ve tanıtmaktır. Buna yönelik olarak oyun terapisi, oyun terapisindeki kuramsal yaklaşımlar, oyun terapisinin gruplardaki uygulama biçimi incelenmiş ve oyun terapisinin gruplarda nasıl kullanıldığını gösteren üç uygulama kısaca tanıtılmıştır. Son olarak oyun terapisi ve gruplarda oyun terapisi kullanımına ilişkin öneriler paylaşılmıştır.

Anahtar sözcükler: Oyun, oyun terapisi, grupla oyun terapisi.

\begin{abstract}
Play therapy has a history of about a hundred years and is a way of counseling with children. In play therapy, children express themselves using play which are their natural languages. There are many different theoretical approaches about play therapy. However, play therapy practices can be grouped under three headings, which are basically directive, non-directive and family play therapies. Nowadays, in addition to individual and family therapies, group therapies are becoming more widespread. In the current literature reviewing to group play therapy abroad, many research found that Turkey was also understood that a limited number of research found.The aim of this study is to consider and introduce play therapy and its application in groups. To this end, play therapy, theoretical approaches in play therapy, and the application of play therapy in groups were examined and three interventions indicating how play therapy is used in groups were briefly introduced. Finally, suggestions on play therapy and the use of play therapy in groups were shared.
\end{abstract}

Keywords: Play, play therapy, play therapy in group. 


\section{GİRIŞ}

Çocuklara yönelik gerçekleştirilen psikolojik danışma uygulamaları yetişkinlere yönelik gerçekleştirilen uygulamalardan daha farklı şekilde ele alınmaktadır. Bu farklılığın oluşmasını sağlayan en temel gereklilik çocukların gelişim dönemleri itibariyle farklı özelliklere sahip olması olarak ifade edilebilir. Oyun terapisinin günümüzde çocuklara psikolojik danışma yapmada çok yaygın olarak kullanıldığ görülmektedir. Bunun nedeni on iki yaş altındaki çocukların kendi duygu ve düşüncelerini sözel olarak sınırlı düzeyde ifade edebilmeleri olarak değerlendirilebilir. $\mathrm{Bu}$ grupta yer alan çocuklarda danışma oturumuna gelmek, oturmak ve yaşadıklarını, hissettiklerini sözcüklerle bir terapiste anlatmaya çalışmak çoğunlukla güç görünmektedir. Bu gruptaki çocukların gelişimsel özelliklerinden kaynaklı olarak konuşmaya dayalı terapi sürecinden faydalanabilecek becerilere yeterince sahip olmadıkları söylenebilir. Bunun yerine çocukların bir terapi oturumunda oyuncakları, sanatı, hikayeleri, kil, kuklalar vb. gibi diğer oynayabilecekleri araçları kullanarak ayrıca canlandırmalar yapıp rol oynayarak terapistle iletişim kurabilmelerinin ve kendilerini ifade edebilmelerinin daha rahat olacağı belirtilmektedir (Axline, 1981; Kottman, 2011).

Çocuklarla psikolojik danışma yapılması gerektiğinde ve oyun çocukların yaşantılarında kendilerini ifade etmenin doğal bir aracı olarak kullanıldığında çocuklar bunu içlerinde biriken gerginlik, hayal kırıklığı, güvensizlik, öfke, korku, karmaşıklık ve şaşkınlık duygularını dışarı çıkarmak amacıyla kullanma firsatı yakalar. Çocuklar bu duygularını oynayarak dışarı çıkardıklarında onlarla yüzleşebilmekte, onları kontrol edebilmekte veya onlardan vazgeçebileceklerini fark edebilmektedir. Böylelikle duygusal olarak rahatlama yaşayan çocuklar, bir birey olarak içlerinde taşıdıkları gücü görebilmekte, kendi başlarına düşünebilmekte ve kararlar alabilmektedirler. Çocuklar duygularını ifade edebilmelerinin sonucunda psikolojik olarak olgunlaşmakta ve böylece kişiliğe yönelik özelliklerini fark edebilmektedir (Axline, 1981). Bu kapsamda bu çalışmada oyun, oyunun çocuğun hayatındaki yeri ve etkileri, buna bağlı olarak oyun terapisi ve oyun terapisinin gruplarda kullanımının ele alınması amaçlanmıştır.

\subsection{Oyun ve Çocuk}

Alanyazın incelendiğinde oyun kavramının ne olduğuna ve neler içerdiğine ilişkin birbirinden farklı tanımlamaların olduğu görülmektedir (Burghardt, 2005; Else, 2009; SuttonSmith, 1997). Bununla birlikte oyunun gerekliliklerinin neler olduğu konusunda evrensel bir kabul bulunmadığı anlaşılmaktadır. Oyun, dışarıdan bakıldığında fark edilebilir ve tanımlanabilir bir etkinlik olarak değerlendirilmekle birlikte oyunun hemfikir olunan bilimsel bir tanımını yapmanın pek çok farklı alandan profesyonel için zor bir durum olduğu anlaşılmaktadır. Ancak temel özelliklerinden söz etmek gerekirse oyun genellikle oynayanlar için eğlenceli, yaratıcılığı, problem çözmeyi, esnekliği, risk almayı, merakı, uyumu ve akışı içeren bir süreç olarak ifade edilebilir (VanFleet, Sywulak ve Sniscak, 2010). Oyun zamanı doldurmak için zihnin boşaltıldığ 1 bir süreç ya da işten geri kalan zamanın dinlenme aktivitesi değildir aksine başarısızlık ya da olumsuz sonuçlara ulaşmaktan duyulan korkudan uzaklaşarak yapmak, düşünmek ve hissetmenin kendiliğinden ve etkin bir şekilde ortaya çıkmasının güzelliğini içeren bir süreçtir. Oyun oynayanlar özgünlük ve yaratıcılıklarını ortaya koyabilecek şekilde özgür bir ortamdadırlar ve bu nedenle süreçte yeni bilgileri özümseyerek içselleştirebilir ve kendilerini dönüştürebilirler. Bu bireyin kendisine yönelik oluşan değişim süreci beraberinde dünyaya olan bakış açısının değişimini de getirir. Böylelikle birey özerkliğine yönelik bir baskı ya da tehdit hissetmeden, kontrolün kendisinde olduğunu derinden hissederek bu değişime kendisini birakır (McMahon, 1992).

Oyun, çocukların hayatının hatırı sayılır bir bölümünü kapladığı için önemli bir süreç olarak ele alınmakta ve bu önemli etkinlik çocuğun hayatında pek çok gelişimsel amaca hizmet etmektedir. Oyunun basitçe gerçekleştirilebilmesi ve güvenli bir ortam oluşturması çocukların karmaşı sosyal etkileşimleri daha rahat deneyimlemelerini sağlamaktadır. Ayrıca oyunun 
sıklıkla bir bağlanma etkisi oluşturduğu ve oyun oynayanların genellikle bir arada kalmak istedikleri gözlemlenmektedir. Dolayısıyla arkadaşlar, kardeşler ve ebeveynlerle oynanan oyunlar çocukların sağlıklı bağlar, bağlantılar ve sonuç olarak güvenli bağlanma geliştirmelerine yardımcı olur. Oyun oynayarak oluşan sağlıklı ve güvenli bağlanma çocukların güvenli sınırlar içinde kendi otantiklikleriyle dünyayı keşfetmelerini sağlamaktadır (VanFleet ve diğerleri, 2010). Örneğin oyun oynayan çocuklar yaşadıkları öfkeyi karşıdakilere ya da kendilerine yansıyacak şekilde ifade etmekten ziyade güven içinde dile getirmeyi öğrenirler. Böylelikle çocuklar yaşantılarıyla içsel bir uyum yakalar ve sonraki gerçek olaylarda daha sağlıklı bir baş etme süreci yaşayabilirler. Oyun ve çocukla ilgili kritik olan başka bir noktanın da oyunun çocuğun sosyal, duygusal, fiziksel, entelektüel vb. gibi bütün gelişim alanlarıyla bağlantılı olmasıdır. Çocuklara uygun olan oyunların bu özelliklere göre belirlenmesine dikkat edilmesi gerektiği belirtilmektedir. Çocukların en yüksek düzeyde fayda sağlayabileceği süreçler oluşturmak için sözü edilen alanlarda en uygun oyunların belirlenmesinin katkı sağlayacağ 1 anlaşılmaktadır (McMahon, 1992).

\subsection{Oyun Terapisi}

Oyun kavramının basitçe tanımlanamamasına benzer olarak oyun terapisinin de kolayca tanımlanamadığı görülmektedir. Her ne kadar oyun terapisi yaklaşımları uzunca bir süredir var olsa da uzmanların bu konuda farklı yaklaşımlar sergilediği anlaşılmaktadır. Örneğin bazı uzmanlar oyuncakları çocuğun duygularını anlatmasını kolaylaştırmak için ayırt etmeksizin kullanırken diğerleri çocuğu ailevi bir soruna odaklayabilmek için bilinçli olarak aile temsili (bir bebek ailesi) oyuncaklar kullanabilmektedir. Ancak oyun terapisi uzmanları için yaklaşımları ne olura olsun oyun oynamanın kendisi tedavi edici olarak değerlendirilmektedir. Bu bakış açısının oyun terapisi yaklaşımlarında ortak olduğu anlaşılmaktadır. Buna göre farklı tanımlar yapılmakla birlikte, tanımların ortak noktaları bulunduğu anlaşılmaktadır. Bu ortak noktalara göre oyun terapisi, terapötik bir ilişki bağlamında sistematik olarak ve oyundaki etkileşimleri kullanarak çocuklarda problem çözme yöntemleri geliştirmeye odaklı ve çocukların psikososyal gelişimlerini desteklemeyi amaçlayan bir süreç olarak tanımlanabilir (VanFleet ve diğerleri, 2010).

Daha ayrıntılı bir şekilde ele alınacak olursa Kottman'a (2011) göre oyun terapisi, küçük çocuklarla danışma yapmanın bir yoludur ve oyunu çocukların kendilerini doğal bir şekilde ifade edebilme aracı olarak görmesine dayanmaktadır. Bu yetişkinlerin yaşadıkları güçlükleri konuşarak ifade etmelerine benzer olarak çocukların duygularını ve problemlerini oynamaları yani canlandırmaları veya oynayarak ortaya çıkarmaları yani keşfetmeleri anlamına gelmektedir (Axline, 1981). Oyun terapisindeki danışmanlık, terapötik etkileşimin temeli olarak çocukların doğal dili olan oyunu kullanmaktadır. Oyun çocukların kendini ifade dilidir ve terapistlere onların dünyalarına erişebilme imkanı sağlamaktadır (VanFleet ve diğerleri, 2010). Oyunda, çocuğun yaptıkları ve söylediklerinin çoğu, çocuğun dünyasındaki ilişkiler ve durumlar hakkında sembolik, mecazi bir betimleme gibi değerlendirilebilir ve bu betimleme çocuğun iletişim biçimini göstermektedir. Çocukların alıcı dilleri ifade edici dillerine göre çoğunlukla daha hızlı gelişmekte ve yaşadıklarını nasıl sözelleştirebileceklerini, sözcüklere dökebileceklerini bilemeseler bile kavramları anlayabilmektedirler. Bu durum çocukların içinde oldukları durumları veya fikirlerini dile getiremeseler bile danışmanların kavramları olması gerektiği gibi kullanarak açıklamalar yapabileceklerini göstermektedir. Bu nedenle terapistler sıklıkla çocukla iletişim kurabilmek adına oyunlarla konuşmayı bir arada kullanabilmektedirler (Kottman ve MeanyWalen, 2016).

Uluslararası Oyun Terapisi Derneği'ne (Association for Play Therapy, 2019) göre oyun terapisi teorik bir model olarak, oyun terapistlerinin oyunun terapötik güçlerini kullanarak danışanlarının psikolojik sıkıntılarını önleme ya da çözümlemeye dayalı olarak en uygun düzeyde büyüme ve gelişmelerini sağlamaya dayalı kişilerarası bir süreç olarak tanımlanmaktadır. Oyun terapisinde genellikle bireyi anlamaya yönelik; sınırları ve çerçevesi çizilmiş bir yaklaşıma bağlı kalarak ilerlemek yerine bireyin kişiliğini gözlemler yoluyla keşfetme ve açıklamaya dayalı bir 
yaklaşım tercih edilmektedir. Bu yaklaşımların temeli her bireyin içinde kendini gerçekleştirmeye yönelik büyük bir güç ve kaynak bulunduğu bakış açısına dayanmaktadır. Kişinin içinde bulunan bu kaynağın büyümeye ve gelişmeye ihtiyacı vardır ve bu nedenle bireyin özgürce hareket etmesine olanak sağlayacak bir alan bu kaynağın en yüksek potansiyele ulaşmasını sağlayacaktır (Axline, 1981). Terapist, oyun terapisinde oyuncaklar, sanatsal araçlar, oyunlar ve bütün diğer oyun araçları vasıtasıyla danışanlarıyla onların (çocukların) dilinden iletişim kurarak süreci ele alır. Çünkü on iki yaş altındaki çocuklar kendi duygu ve düşüncelerini sözel olarak sınırlı düzeyde ifade edebilmekte ve bu çocuklar için danışma oturumuna gelmek, oturmak, yaşadıklarını sözcüklerle bir terapiste özetlemek çoğunlukla güç görünmektedir. Bu özelliklerinden kaynaklı olarak çocukların konuşmaya dayalı terapi sürecinden faydalanabilecek becerilere sahip olmadıkları söylenebilir. Ancak çocuklar bir terapi oturumunda oyuncakları, sanatı, hikayeleri ve diğer oynayabilecekleri araçları kullanarak terapistle iletişim kurabilmektedirler (Kottman, 2011). Dolayısıyla tercih edilen oyun terapisi yaklaşımına bağlı olarak terapistler danışanlarıyla iletişim kurabilmek amacıyla pek çok farklı yol ve yöntem tercih edebilmektedirler. Bunlar arasında serbest oyunlar, yönlendirilmiş oyunlar, sanat teknikleri, metaforik hikâye anlatımları, bibliyoterapi, drama terapisi stratejileri, macera terapisi teknikleri, hareket ve dans, müzik ya da terapötik olarak etkili diğer yaratıcı süreçler sayılabilir (Kottman ve Meany-Walen, 2016).

Pek çok farklı oyun terapisi yaklaşımı olmakla birlikte bütün bunları temelde üç genel başlık altında ifade etmek mümkündür: Yönlendirici olan (directive) yapılandırılmış yaklaşımlar, yönlendirici olmayıp (nondirective) çocuk merkezli olan yaklaşımlar ve aile oyun terapileri. Yönlendirici olan ve olmayan yaklaşımlar arasındaki temel fark terapistin sürece müdahil olma biçimiyle kendini göstermektedir (Gil, 1991). Buna göre yönlendirici oyun terapisinde terapist çocuğa karşı ve süreç içinde yorumlayıcı, yönlendirici bir tutum içindeyken ikinci yaklaşımda çocuğu yönlendirmemekte ve yorum yapmamaktadır (Axline, 1981). Yönlendirici yaklaşımda genellikle terapist çocuğun oynayacağı oyunu ve oturumun gidişatını belirlemektedir. $\mathrm{Bu}$ yaklaşımlarda en önemli özellik terapistin lider konumunda olmasıdır. Bu yaklaşım için verilebilecek örnekler arasında Bilişsel-Davranışçı Oyun Terapisi ve Yapılandırılmış Oyun Terapisi yaklaşımları sayılabilir. Yönlendirici olmayan yaklaşımda ise çocuk oynayacağı oyunu, kullanacağı oyuncakları kendi seçmekte ve terapist çocuğa oturumun gidişatını belirlemesi konusunda izin verici bir tutum sergilemektedir. Çocuğun kendi yönelimine göre hareket etmesine izin veren bir tutum sergiler. Bu yaklaşım için en temel örnek Çocuk Merkezli Oyun Terapisi'dir. (Gil, 1991; VanFleet ve diğerleri, 2010). Yönlendirici olmayan yaklaşımda bireylerin kendi problemlerini kendilerinin çözebileceği yeterlilikte oldukları düşünülmekte ve çocukların büyüme dürtüsüyle olgun davranışlar sergileyebilme kapasitesine sahip oldukları değerlendirilmektedir. Buna göre bu yaklaşımda bireyin "kendisi”" olabilmesi için özgür bir alan yaratılmakta ve bireye benliğini değiștirmesi konusunda baskı yapılmaksızın birey tamamıyla kabul edilmektedir (Axline, 1981). Üçüncü grup olan aile oyun terapilerinde ise çocuk-ebeveyn ilişkisinin güçlendirilmesi üzerine odaklanılır. Bu yaklaşımda sağlıklı bağlanmayı geliştirerek çocukların problemli davranışlarını azaltmak amaçlanmaktadır. Bu yaklaşıma örnek olarak Theraplay ve Filial Oyun Terapisi gösterilmektedir (VanFleet ve diğerleri, 2010).

Oyun terapisi her ne kadar çocuklarla psikolojik danışma yapmanın en etkili yöntemi olarak değerlendirilse de bütün çocuklar ve sorun alanları için en etkili yaklaşım olduğunu söylemek mümkün değildir. Buna göre oyun terapisi bazı durumlarda tek başına etkili bir müdahale iken bazı durumlarda ise başka bir müdahaleye entegre olarak kullanıldığında daha etkili olmaktadır. Ancak oyun terapisinin sağaltım için bir seçenek olmadığı durumlar da bulunmaktadır (Kottman, 2011).

Buna göre oyun terapisinin; kaygı, depresyon ve gelişimsel gecikmeler, davranış problemleri, acı-keder ve mükemmeliyetçilik gibi sosyal problemlerde etkili olduğu anlaşılmaktadır. Bunların yanı sıra boşanma, ihmal, istismar, aile içi şiddet ve diğer problemler, travmalar gibi konularda da oyun terapisinin uygun ve etkili sonuçlar doğurduğu belirlenmiştir (Danger, 2003; Davenport ve Bourgeois, 2008; Green, 2008; Huth-Bocks, Schettini ve Shebroe, 
2001; Karcher, 2002; Morrison, 2009; Mullen, 2002; Paone ve Douma, 2009; Tyndall-Lind, Landreth, ve Giordano, 2001). Diğer taraftan bağlanma bozukluğu, dikkat eksikliği/hiperaktivite bozukluğu (DEHB), otizm spektrum bozukluğu, duygu durum bozukluğu, özel öğrenme güçlüğü, zihinsel gerilik ve konuşma güçlüğüne sahip çocuklarda ise oyun terapisinin tedavi müdahaleleriyle birlikte kullanılmasının daha uygun olduğu belirtilmektedir. Dahası bu tanılara sahip çocuklarda ilaç tedavisi, diğer müdahaleler, aile katılımı ve oyun terapisinin bir arada olduğu planlamaların daha uygun olduğu anlaşılmaktadır (Kale ve Landreth, 1999; Mastrangelo, 2009; Ray, Schottelkorb ve Tsai, 2007; Ryan, 2004).

\subsection{Oyun Terapisine Yönelik Kuramsal Yaklaşımlar}

Oyun terapisi uygulamalarının pek çok farklı kuramsal temele dayandırılarak ele alındığı görülmektedir. Buna göre bu bölümde farklı kuramsal yaklaşımlara dayalı olarak geliştirilen oyun terapisi yaklaşımlarının bazıları ve bunlara ilişkin temel özellikler kısaca açıklanarak ele alınmıştır.

\subsubsection{Psikodinamik Oyun Terapisi}

Psikoterapinin ilk uygulayıcısı olan Sigmund Freud aynı zamanda oyunu da terapötik bir araç olarak kullanan ilk kişidir. Freud'dan sonra oyunu müdahalelerinde Hermine HugHellmuth' un kullandığı bilinmektedir. Daha sonrasında ise psikodinamik oyun terapisi için kuram ve uygulama olarak belirli formülasyonlar Melanie Klein ve Anna Freud gibi psikanalistlerce geliştirilerek uygulanmaya devam etmiştir (Gil, 1991, ss. 28). Melanie Klein (1955) ilk psikanaliz vakası olan 5 yaşındaki bir erkek çocuğuna yönelik çalışırken onun yaşadığı anksiyeteyi ve buna bağlı geliştirdiği savunmaları nasıl daha rahat anlayabileceğini araştırdığını belirttiği çalışmasında yanıtı çocuğun oyuncaklarında ve oyunlarında bulduğunu ifade etmektedir. Buna göre yetişkinlerin sözcüklerle anlattıklarını çocuğun oyunlarında davranışlarıyla ortaya koyduğunu gözlemlemekte ve bu şekilde bilinç öncesi ve bilinç dışında olan materyali yorumlayabilmeye başladığını aktarmaktadır.

Psikoanalitik/psikodinamik oyun terapisinin amacı çocuğun artık daha fazla sessiz kalamadığı durumlarla ilgili olarak yaşadığı iç çatışmalarını dışa vurmasını sağlamak şeklinde ifade edilmektedir (Cohan, Chavira ve Stein, 2006). Kendi oyuncaklarıyla oynadığı oyunların ve oyun sırasında sergilediği davranışların çocukların psikanalitik olarak fantezilerini, iç çatışmalarını, duygularını, deneyimlerini ve savunma mekanizmalarını yorumlanmaya olanaklı hâle getirdiği belirtilmektedir (Klein, 1955).

\subsubsection{Adleryan Oyun Terapisi}

Adleryan oyun terapisi Alfred Adler'in 20. yüzyılın başlarında geliştirmiş olduğu Bireysel Psikoloji olarak adlandırılan kuramına dayanmaktadır. Bu kuramın merkezinde yer alan bireylerin kişiliklerinin nasıl oluştuğu, çevrelerinde bulunan insanlarla nasıl bir etkileşim içinde bulundukları, motivasyon kaynakları ve yaşadıkları zorlanma durumlarının neler olduğudur (Corey, 2015). Adleryan oyun terapisinin de bu açılardan ele alınmasını gerektirmektedir. Adleryan oyun terapisti bir çocuğun davranışlarını gözlemlerken onu toplumun bir parçası olarak ele almakta, izole ve tek başına bir birey gibi düşünmek yerine diğer insanlarla oluşturduğu bütünlük bağlamında değerlendirmektedir. Bu bakımdan çocuğun ilk sosyalleştiği ortamın aile olduğu düşünüldügünde çocuk ile ebeveyn ve kardeşler arasındaki ilişkilerin önemi ortaya çıkmaktadır. Bununla birlikte çocuğun etkinlik alanına bağlı olarak okul, mahalle gibi diğer sosyalleşme alanları da bu bağlama dahil edilmektedir. Adleryan yaklaşıma göre oyun terapisine çoğunlukla sosyal ilgileri ve iletişimleri düşük çocuklar ve aileler gelebilmekte ve ilk olarak bu sosyal ilginin ve ilişkilerin arttırılmasına yönelik müdahaleler yapılmaktadır (Kottman ve Meany-Walen, 2016). 


\subsubsection{Jungyan Analitik Oyun Terapisi}

C. G. Jung, insan ruhunun ya da psişenin kendini düzenleyebilen ve nasıl iyileşebileceğini bilen bir yap1 olduğuna inanmaktadır. Ona göre bireyin bütünleşmeye, büyümeye ve bireyselleşmeye yönelik dürtüsü yani bireyin eşsiz potansiyelini ortaya çıkarma dürtüsü en temel dürtüdür. Jung ruhun veya psişenin kendini rüyalar ya da yaratıcı süreçlerle gösterdiğini ifade etmektedir. Bu nedenle danışanlarının kendi içsel sembol ve fantezilerini yazarak, çizerek, boyayarak veya heykel yaparak belirlemesini ve ortaya çıkarmasını sağlamaya çalışmıştır. Jung bu yönüyle büyüme ve dönüşmenin de güven ve koruma içeren terapötik bir ortamda bireyin kendi içsel süreçlerini takip etmesiyle oluşacağını belirtmektedir (Allan ve Brown, 1993). Jungyan Analitik Oyun Terapisi'nde benzer şekilde çocuklarda da psişenin kendini iyileştirme potansiyeli bulunmaktadır. Arketiplerin yardımıyla çocukların davranışları organize edilebilir ve çocuklar için de terapide kullanılabilecek yazma, çizme, drama ve sanat vb. yöntemler ele alınabilir. Jungyan Analitik Oyun Terapisi'ne göre böylesi yaratıcı süreçlerden geçen çocuklar iyileşmeye yönelik bir dönüşüm gösterirler (Carmichael, 2006b, ss. 90). Arketipleri insan davranışlarını spesifik olarak temsil eden kültürel bazı imgelere karşı hissedilen duygular olarak ele alan Jungyan yaklaşım bunları temel olarak rüyalarda, fantezilerde ya da mitolojide ortaya çıkan dünya anne, üçkağıtçı, yaşılı bilge adam gibi figürler olarak ifade etmektedir. Buna göre Jungyan oyun terapistleri de çocukların belirledikleri sembolleri veya arketiplerini terapi süreci içinde bulundukları makro sistem bağlamında değerlendirmekte ve çocukların da bu sembolleri kendi fenomenolojik bakış açılarından anlamalarına olanak sağlamaktadırlar (Green, 2008).

\section{3..4. Çocuk Merkezli Oyun Terapisi}

Çocukların problemlerini ele alan temel yaklaşımlardan biri de çocuk merkezli oyun terapisidir. Açık ve net prensiplere sahip ve özel beceriler içeren bu yaklaşım öğretilebilir bileşenlerden oluşması nedeniyle çocuk terapisteri tarafından yaygın bir şekilde kullanılmaktadır. $\mathrm{Bu}$ yaklaşım yönlendirici olmamayı içerir ve çocuğun liderliğini terapistin takip ettiği bir süreç olarak nitelendirilmektedir. Yapılacak etkinliklerin ve oynanacak oyunların çocuk tarafından seçildiği Rogeryen/Axlinyen tarzda bir oyun terapisi şekli olarak tarif edilmektedir (VanFleet ve diğerleri, 2010, ss. 18). Bu yaklaşım Virginia M. Axline tarafindan geliştirilmiştir. Carl Rogers'ın öğrencisi olan Virginia M. Axline yetişkinlerin empati, saygı, koşulsuz kabul, güven, özerklik, otantiklik/özgünlük, uyumluluk yaşadıkları ortamlarda sorunlarıyla yüzleşebildiklerini ve çözüme ulaşabildiklerini gördüğünde bir oyun odası içinde çocuklara da bu şartların sağlanmasının onların sorunlarını dile getirmelerini ve çözümlemelerini sağlayabileceğini düşünmüş ve bunu uygulamaya geçirmiştir (Axline, 1981, ss. 9). Virginia M. Axline (1981, ss.73-74) çocuk merkezli oyun terapisi için sekiz temel ilke geliştirmiştir. Bu sekiz ilke basit gibi görünmekle birlikte çocukta gelişimi ve değişimi oluşturmanın temelini oluşturan ilkelerdir. Bu ilkeler şöyledir:

1) Terapist mümkün olan en kısa sürede çocukla sıcak ve arkadaşça bir ilişki kurmalıdır.

2) Terapist çocuğu olduğu gibi kabul etmelidir.

3) Terapist terapide izin verici bir tutum sergilemeli ki çocuk duygularını tamamen ve özgürce ifade edebileceğini hissedebilmelidir.

4) Terapist çocuğun yaşadığı duygulara yönelik uyanık/farkında olmalı ve bu duyguları çocuğa davranışları konusunda içgörü kazanabilmesi için yansıtmalıdır.

5) Terapist olanaklar sağlandığında çocuğun sorun çözme becerisine yönelik büyük bir sayg1 tutumu içinde olmalı, değişiklik ve seçim yapma sorumluluğunu çocuğa bırakmalıdır.

6) Terapist çocuğun konuşmalarını ve eylemlerini hiçbir şekilde yönlendirmeye çalışmamalıdır. Bu süreçte lider çocuktur, terapist ise takipçi.

7) Terapist süreçte acele etmemelidir. Terapist tarafından doğalında ilerleyen aşamalı bir süreç olarak tanınmalıdır. 
8) Terapist süreçte sadece terapinin gerçek dünyayla bağlantısını kurmak ve çocuğun ilişkideki sorumluluğunu fark ettirmek adına bazı sınırlar belirleyebilir.

Bu sekiz ilke dışında çocuk merkezli oyun terapisinde ayrıca kullanılan dört temel beceri yer almaktadır. Bu temel beceriler yapılama, empatik dinleme, çocuk merkezli hayalî oyun ve sınırları belirleme. Bu becerilerden ikinci ve üçüncü beceri terapistin çocuğun duygularını, davranışlarını ve arzularını anlaması ve kabul etmesi için kullanılanlardır. Birinci ve dördüncü becerilerin ise güvenli bir ortam oluşturma, davranışsal problemler ve çatışmaların oluşmasını önleme ve bunlarla başa çıkabilmek için kullanıldıkları söylenmektedir (VanFleet ve diğerleri, 2010, ss. 58).

\subsubsection{Bilişsel- Davranış̧̧ı Oyun Terapisi}

Bilişsel-davranışçı oyun terapisi Bilişsel Terapi, davranış değişikliği ve duygusal gelişim ile ilgili kuramların entegrasyonuna ve bu kuramlardan türetilen müdahalelere dayanmaktadır. Bilişsel-davranış̧̧ı oyun terapisi yaklaşımından önce oyun terapisi tekniklerinin çoğunluğu psikodinamik veya danışan/çocuk merkezli kuramlara dayanmaktaydı. Bu kuramsal yaklaşımların ikisinde de oyun terapisi yapılandırılmamış ve çocuk tarafından yönlendirilmektedir. Bilişsel-Davranışçı Oyun Terapisi, çocuk psikoterapisine farklı bir kuramsal yaklaşım sunmuştur. Buna göre Bilişsel-Davranışçı Oyun Terapisi ile diğer oyun terapileri arasındaki farklar; yaklaşımın yapısı, psikoeğitimsel unsurlar barındırıyor olması ayrıca hedef odaklı olması ve işbirliğine dayanması yani, hem çocuk hem de terapist tarafından yönlendiriliyor olmasıdır. Oyuncaklar bu yaklaşımın genelinde, uyumsuz inançların olumlu benlik ifadelerine dönüştürülmesi amacıyla bilişsel stratejileri modellemek için kullanılmaktadır. Bu yaklaşımda çoğunlukla, oyun materyalleri aracılığıyla yapılan müdahaleler modellenerek, gelişimsel açıdan hassas bir şekilde sunulmaktadır (Knell, 2015; Knell ve Dasarı, 2010).

\subsubsection{Ekosistemik Oyun Terapisi}

Ekosistemik yaklaşım 1980'lerde pek çok psikolojik, sosyolojik çalışmayı, ekolojik ve sistem teorilerini birleştirerek ortaya çıkmış ve ortaya koyduklarını hemen hemen aynı zamanlarda oyun terapisine uygulanmıştır. Ekosistemik yaklaşımın oyun terapisindeki amacı oyun terapistine vaka formülasyonlarında veya müdahalelerinde çok kapsamlı bir sistemik bakış açısı kazandırmaktır (O'Connor, 2011, ss. 299). Ekolojik yaklaşım, özünde çocukların yaşadığı problemlerde organizma ve çevrenin ortak etkisinden söz etmektedir. Davranışların gerçekleşmesinde sadece bireye odaklanmak yerine ekosistemin ya da etkileşim yaşanan sistem içinde yer alan canlılar ve ortam olmak üzere bütün habitatın etkilerini incelemeye dayalıdır. Bu yaklaşımda insan doğasına ilişkin araştırmalara başvurulmakta ve insanların doğal gelişim evrelerine dayalı müdahalelerin önemi üzerinde durulmaktadır (Apter, 1977).

Oyun terapisine yönelik olarak da bu yaklaşımın sözü edilen özellikler bağlamında iki önemli noktayı ön planda tuttuğu söylenebilir. Bunlardan ilki etkili müdahalelerin planlanmasında ve uygulanmasında çocuğun yaşadığı sorunun kökenini ve doğasını anlayabilmek adına gelişimini göz önünde bulundurma ve bunun öneminin farında olmaktır. Çünkü gelişme hem diğer sistemleri etkilemekte hem de diğer sistemlerden etkilenmektedir. Bu yaklaşımda çok kısa süren ve ani değişimler içeren gelişim süreçleri bile hem çocukta yaratacağ 1 stres ve bozulma bakımından hem de terapistin daha uygun bir müdahale planı hazırlayabilmesine ilişkin önemli görülmektedir. Ekosistemik Oyun Terapisi'nin bir diğer özelliği de çocukların oyun terapisi oturumlarına deneysel ve bilişsel-sözel müdahaleleri entegre etmesinin üzerinde durmasıdır. Daha düşük gelişimsel seviyelerde olan çocuklar, daha fazla deneyime dayalı müdahaleleri içerecek oturumlara ihtiyaç duymaktayken daha yüksek gelişimsel seviyelerdeki çocuklar, fikirlerini pekiştirmek için mutlaka deneyime ihtiyaç duymadan sorunları kavramsal olarak çözebilir şeklinde bir yaklaşım içermektedir (O'Connor, 2011; O’Connor, 2016). 


\subsubsection{Geştalt Oyun Terapisi}

Geştalt kavram olarak toplamın ya da bütünün kendisini oluşturan parçalardan daha fazla olduğu ve parçalar arasındaki ilişki devam ettikçe bütünlüğün de devam edeceği şeklinde açıklanmaktadır. Geştalt terapi ise şimdi ve buradanın farkındalığına odaklı, insanlar ve çevreleri arasındaki etkileşim ve bağımlılığı vurgulayan fenomenolojik, varoluşsal ve bütüncül bir yaklaşım olarak ifade edilmektedir. Buna göre seçimlerinin farkında olmak ve sayg1 içinde davranışlar sergileyerek hayatının önemini belirlemek ve göstermek bireyde organizmik öz düzenlemeyi geliştirmektedir (Corey, 2015). Geştalt Oyun Terapisi, çocukla oyun terapisi sırasında Geştalt Terapi'nin prensiplerini ve tekniklerini kullanan psikoterapötik bir yaklaşım olarak kabul edilmektedir. Bu yaklaşıma göre terapötik bir ilişki içinde ve temas geliştirerek belirli bir süre boyunca, çocuklara sözlü ve sözsüz olarak kendi duygularını teyit etme, düşüncelerini ifade etme ve kendilerini yetiştirme, büyütme firsatı verilmektedir. Ayrıca farklı aşamalar boyunca pek çok oyun şekli ve teknik kullanılabilmektedir (Blom, 2006, ss. 17-20).

Geştalt Oyun Terapisi, yaklaşımın temel kavramları olan holizm/bütünlük, homeostazis/organizmik öz düzenleme, şekil-fon, geştaltın oluşma ve bozulma süreci, temas ve temas bozuklukları, kutuplar ve kişilik yapısına dayanır. Buna göre çocuklar holistik/bütüncül varlıklardır. Fiziksel, duygusal, ruhsal yönleri, dilleri, düşünceleri ve davranışlarının bütününden oluşurlar. Homeostazis/organizmik öz düzenleme kavramları, çocuğun sürekli olarak fiziksel, duygusal, sosyal, ruhsal veya entelektüel ihtiyaçlar gibi farklı nitelikteki gereksinimleri olduğu göstermektedir. İhtiyaçları karşılamak için eylemin gerçekleştiği süreç ise organizmik öz düzenlemenin gerçekleştiği süreçtir. Öz düzenleme kavramı iç ve dış olmak üzere ikiye ayrılır. İç öz düzenleme doğal olarak kendiliğinden gerçekleşirken dış öz düzenleme dışardan olan birine karşı zorunu gerçekleştirilmesi beklenen düzenlemedir. Geştalt Oyun Terapisi'nde amaçlanan çocuğun bu bütünlük içinde şimdi ve burada kendini fark edebilmesi ve bütünlüğünü sürdürebilmesidir (Blom, 2006, ss. 22-24).

\subsubsection{Filial Oyun Terapisi}

Ekolojik bir bakış açısıyla ele alındığında çocuğun işlevselliği çevredekilerin tepkilerine bağlı olarak gelişmekte ve bu durum çocuğa ve ailesine verilen desteği içermektedir. Filial oyun terapisi de ebeveyne, oyun terapisti rehberliğinde çocuğun birincil terapisti olma firsat1 sunmaktadır. Bu yaklaşım çocuk merkezli olmakla birlikte değişimi kolaylaştırmak ve üzerinde çalışılacak bağlamı oluşturmak için çocukla ebeveynleri arasındaki bağa dayanmaktadır. Filial Terapi veya çocuk-ebeveyn ilişkisi eğitimi kuramsal olarak bütünleştirici ve eklektik bir yaklaşım olarak değerlendirilebilir. Genel olarak psikodinamik, hümanistik, davranışçı, bilişsel, sosyal öğrenme, bağlanma ve aile sistemleri kuramlarının unsurlarını birleştirmekte birlikte aslında birincil kuramsal temeli Danışan/Çocuk-Merkezli Oyun Terapisine dayanmaktadır (Glazer, 2010, ss.90-91). Filial Oyun Terapisi çocuk merkezli oyun terapisinde çocuk için gerekli olan ve gerçekleştirilen bütün uygulamaları alır ve yanına ayrıca anne babanın da süreçte aktif katılımını ekleyerek devam eder (VanFleet ve diğ., 2010, ss. 127). Filial oyun terapsi psikoeğitimsel bir yaklaşıma sahiptir. Süreçte ebeveynlere çocuk merkezli yaklaşımın becerileri öğretilerek çocuklarının yaşadığı duygu ve davranış problemlerinde başa çıkabilmeleri için yardımcı olabilmeleri sağlanmaktadır. Ebeveynler öncelikle bir filial terapi uzmanından süpervizyon alarak süreçte terapötik bir ajan gibi çalışır ve kendilerini geliştirir. $\mathrm{Bu}$ açıdan değerlendirildiğinde Filial Terapi'nin ebeveynler ve çocukları arasındaki yaşam boyu süren sağlıklı ilişki ve iletişimi geliştirmeye yönelik katkısı oldukça önemli görünmektedir. Ebeveynler sadece o dönemde yaşanan bir sorunda değil sonraki süreçler için de donanımlı bir hâle gelmektedirler (Guerney, Stollak ve Guerney, 1971).

\subsection{Oyun Terapisinin Gruplarda Kullanımı}

Oyun terapisi bireysel ve aileyle birlikte uygulanmasının yanı sıra çocuklardan oluşturulan gruplarda da uygulanmaktadır. Grupla oyun terapisi, çocukların kendi becerilerini değerlendirebilecekleri, kendilerini farklı ve alternatif biçimlerde ifade edebilecekleri ve 
bilgilerini kapasitelerine uygun maksimum avantajları elde edebilecek şekilde nasıl kullanabileceklerini öğrendikleri bir ortam sağlamaktadır (Chinekesh, Kamalian, Eltemasi, Chinekesh ve Alavi, 2014). Grupla oyun terapisi müdahalesinin genel hedefleri olarak katılımcıların özdenetim kurma, sorumluluk alma, duygularını ifade etme, kendini ve başkalarını kabul etmeyi öğrenmeleri, benlik saygısını ve öz güveni geliştirmeleri ayrıca sosyal beceriler kazanmaları ile birlikte depresyon ve kaygı düzeylerinin azaltılması ifade edilebilir (Landreth, 2002). Grupla oyun terapisi terapötik olarak çok güçlü bir müdahale olmasının yanısıra bireysel terapiye göre terapinin amaçlarına ulaşılmasında ilgi uyandıran ve etkileyici bir ortam oluşturmaktadır (Sweeney, Baggerly ve Ray 2014). Ayrıca yeni pek çok öğrenmenin oluşması ve uygun olmayan tutum ve davranışların bırakılması açısından en etkili ve ekonomik müdahale olduğu belirtilebilir (Bleck ve Bleck, 1982). Bu müdahalenin uygulanması sürecinde çocuklar baş etme davranışları, problem çözme becerileri, alternatif kendini ifade yolları için uygun bir ortamda bir terapistin kolaylaştırıcılığ 1 ile desteklenirken bir taraftan da gerçek deneyimlerle diğer üyelerin varlıklarını, düşüncelerini, davranışlarını, duygularını gözlemleyebilmektedirler. $\mathrm{Bu}$ açıdan ele alındığında grup üyelerinin her biri kişisel ve kişilerarası durumlarını, sorunları keşfetme imkânı bulmaktadırlar. Böylelikle bu süreç hem grup lideri hem de diğer üyeler için daha bilinçli bir hâle gelmeyi sağlar. Çocukların kendilerini daha fazla tanımasını, bireyselliğinin, özgünlügünün, benzersizliğinin farkına varmasını deneyimleyebildiği bir ortam oluşturulmuş olur (Ray, 2011; Sweeney ve diğerleri, 2014).

Gerçekliğin kontrollü bir ortamda deneyimlenmesi için grupla oyun terapisi uygulamalarının gerçekleştiği ortamlarda gerçek yaşamı yansıtan araçların kullanılması önemli bir durum olarak karşımıza çıkmaktadır. Buna göre gerçek hayatı çağrıştıran pek çok oyun malzemesinin arasında seanslarda kullanılmak üzere oyun terapisi çantası için öneriler şöyle belirtilebilir: Bükülebilir bir oyuncak bebek ailesi, bant şeritleriyle sınırları belirtilmiş odalara sahip olan bir karton bir ev, biberon, plastik tabaklar, küçük bir araba, küçük bir uçak ve bir telefon. Saldırganlığın ifade edilebilmesini sağlayacak kelepçe, dart tabancası, lastik bıçak, oyuncak askerler gibi eşyalar ve ek olarak çocuğun yaratıcılığını hareket geçirerek kendisini farklı şekillerde ifade edebilmesini sağlayacak küçük düz bir maske, kâğgtlar, boya kalemleri, makas vb. gibi kullanılabilecek araçlar sayılabilir (Landreth, 2002).

Oyun terapisinin gruplarda uygulanmasının etkililiğine ilişkin pek çok araştırma bulunmaktadır. Bunlar arasında belli bir kuramsal yaklaşımı ön plana çıkaran araştırmalar; Danışan/Çocuk Merkezli Oyun Terapisi (Baggerly ve Max-Parker, 2005; Baggerly, 2004; Candan, 2017; Cheng ve Ray, 2016), Yapılandırılmış Oyun Terapisi (Bleck ve Bleck, 1982), Adleyan Oyun Terapisi, (Meany-Walen, Bullis, Kottman ve Taylor, 2015), gelişimsel oyun terapisi (Gumaer, 1984), Bilişsel-Davranışçı Oyun Terapisi, (Ngamthipwatthana, Kiattisirichai, Hosiri ve Manussirivithaya, 2018) olmakla birlikte belirli konulara yönelik olarak planlanan örneğin; yaratıcılığın geliştirilmesi ve öfke kontrolü (Jarareh, Mohammadi, Nader ve Moosavian, 2016), çocuk cinsel istismarı, (Jones, 2002), çok kültürlülük konuları (Su ve Tsaı, 2016), sosyal kaygıyla başa çıkma (Teke, 2019), utangaçlıkla başa çıkma (Yıldız, 2015) müdahalelerin de bulunduğu belirlenmiştir.

$\mathrm{Bu}$ çalışmalara ek olarak grupla oyun terapisi müdahalesiyle çocuklarda pek çok beceri ve yeterliliğin geliştirildiği de anlaşılmaktadır. Örneğin grupla oyun terapisi sürecine dâhil olan çocuklarda sonrasında akranları ve yetişkinlerle işbirliğine dayalı ilişkilerde ve arkadaşlık kurma konusunda gelişme olduğu, sınıftaki aktivitelere ve akademik konulara ilişkin ilgilerinde artış olduğu, anlaşılmaktadır (Meany-Walen ve diğ., 2015). Ayrıca çocukların grupla oyun terapisi aldığında sosyal ve duygusal olarak geliştiği, sosyal anlamda yeterlilik duygusu ve empati kazandığı belirlenmiş (Cheng ve Ray, 2016) ek olarak başka bir araştırmada 8-10 yaşlarındaki çocuklarda agresif davranışların azaltılarak, öz kontrol becerilerinin kazandırıldığı sonucuna ulaşılmıştır (Ngamthipwatthana ve diğ., 2018). Yapılan diğer bir araştırmada ise grupla oyun terapisinin bir önceki araştırma sonuçlarına benzer olarak agresyon davranıșlarını azalttığ bunun yanısıra çocuklarda yaratıcılığı artırdığ 1 tespit edilmiştir (Jrareh, 2016). Grupla oyun 
terapisi çocukların yanı sıra terapistlerin yeterliliklerini de desteklemekte öz güvenlerinde artma, öğrenilen becerilerle sınıf içi davranışların gelişmesi ve önemini fark ettikleri için çocukların fikirlerini süreçte daha fazla almaya dikkat etme gibi sonuçların elde edildiği görülmektedir (Hess. Post ve Flowers, 2005).

Grupla oyun terapisine ilişkin araştırmalar incelendiğinde gruplarla gerçekleştirilen oyun terapisinin pek çok farklı uygulama biçimi olduğu anlaşılmaktadır. Örneğin, ölüm ve yas konusunda grupla oyun terapisi uygulamalarında çocukların bu travmatik yaşantılarını normalleştirmek ve evrensellik duygusunu kazandırmak, sosyal destek sağlanarak diğerleri için önemli olduklarını hissettirmek, hasar görmüş kontrol duygularını iyileştirmek, duygularının önemini göstermek, bu duyguları ifade edebilmeleri için alternatif yollar ve kayıpları ile bağlantı kurmalarını sağlamak amacıyla, gelişimsel özellikler düşünülerek yaşlarına göre 3-5, 6-12, 13 18 şeklinde gruplanan çocuklarda süreç yaklaşık bir yıl boyunca haftada bir gün ve bir buçuk saat süren oturumlar şeklinde planlanmıştır (Schuurman ve DeCristofaro, 2007, ss. 177-185). Başka bir araştırmanın ise 5-10 yaşları arasında 22 Afro-Amerikan çocuğun katılımıyla, kültüre duyarlı, çocuk/danışan odaklı oyun terapisi müdahalesinde üç alanda (kardeş ilişkileri, arkadaşlık ilişkileri ve uygunluk), ikişerli gruplarla çocukların düşük öz saygı, depresyon veya agresyon gibi duygu veya davranış problemlerinin üstesinden gelmeleri amaciyla 9-11 seans olarak haftada bir bazen de iki gün bir araya gelinecek şekilde planlandığı görülmektedir. Çocuk/danışan odaklı bu çalışmada yargılayıcı ifadelerden kaçınmak, güvenli, kabul eden bir atmosfer yaratmak, duyguları yansıtmak, karar vermeyi kolaylaştırmak, benlik saygısını artırmak, terapötik sınırların belirlenmesi ve tedavi edici oyuncaklar sağlamak gibi (Landreth, 2002)'nin belirttiği yaklaşımın temel ilkeleri uygulanmıştır (Baggerly ve Max-Parker, 2005). Benzer şekilde çocuk/danışan odaklı başka bir uygulamada haftalık olarak bir bazen de iki kere bir araya gelinerek, otuzar dakikalık, toplamda 9-12 oturum arasında değişen bir süreç planlanmıştır. Bu çalışmanın amacı evsiz çocuklarda benlik kavramını geliştirme, depresyon ve kaygı düzeylerini azaltma olarak belirlenmiştir (Baggerly, 2004). Adleryan oyun terapisine dayalı olarak yürütülen bir diğer grup müdahalesinde ise sürecin 5-6 yaşlarında, okulda yıkıcı davranışlar sergileyen çocuklara yönelik olarak, 45 dakika süren oturumlarla toplamda 6 oturum olarak planlandığ1 görülmektedir (Meany-Walen ve diğerleri, 2015). Başka bir kuramsal yaklaşım olan Bilişsel Davranışçı yaklaşıma dayalı bir grupla oyun terapisi müdahalesi ise bir bireysel oturum ve 14 grup oturumu olarak oluşturulmuştur. Katılımcılar 8-10 yaşlarında olan toplam 12 erkek çocuktan oluşturulmuştur. Oturumlar 7 hafta ve haftada iki gün, 40-50 dakika sürecek şekilde yürütülmüş̧ür (Ngamthipwatthana ve diğ., 2018). Türkiye'de bu konuda rastlanan sınırlı sayıda araştırma incelendiğinde ilkokul öğrencilerine yönelik hazırlanan 7 oturum ve oturumların haftada bir gerçekleştirilmek üzere planlandığı sekiz öğrenciyle yürütülen bir araştırmanın (Yıldız, 2015) yanısıra yine ilkokul öğrencilerine yönelik olarak hazırlanan ve sekiz çocukla yürütülen bir uygulamanın haftada bir gün, 8 oturum ve her oturumun 40 dakika olarak planlandığı görülmektedir (Teke, 2019).

Elde edilen verilere göre grupla oyun terapisinde standart bir uygulanma biçimi olmamakla birlikte genelde 7-12 oturum arasında planlandığ 1 ve oturum sürelerinin de ortalama 30-40 dakika olarak planlandığ 1 söylenebilir. Türkiye' deki oyun terapisi gruplarında üye sayıs1 daha fazla olmakla birlikte yurtdışında bu sayının iki veya üç olarak da belirlendiği anlaşılmaktadır. Grupla oyun terapisi müdahalesinde gruptaki üye sayısı çocukların en yüksek düzeyde fayda sağlamasını etkileyen önemli bir nokta olarak belirtilmektedir. Buna göre çocuk/danışan odaklı oyun terapisti Axline (1981) oluşturulan gruplarda sekiz üyeye kadar bulunabileceğini ifade ederken Ray (2011) iki veya üç çocuğun bulunacağ gruplardan daha fazla yarar sağlanacağını belirtmektedir. Son dönemlerde yurtdışında yapılan araştırmalarda terapi gruplarının iki veya üç üyeden oluşturulduğu anlaşılmaktadır (Baggerly, 2004; Baggerly ve Max-Parker, 2005; Cheng ve Ray, 2016; Meany-Walen ve diğerleri, 2015). 
Sonuç olarak yürütülen müdahalelerin standartlaştırılmadığı bunun yerine grup üyelerinin ihtiyaçlarına, kişisel özelliklerine ve hemen bütün gruplarda gelişimsel döneme ilişkin özelliklerine göre değerlendirmeler ve planlamalar yapıldığı ifade edilebilir.

\subsubsection{Oyun Terapisinin Gruplarda Kullanımına İlişkin Uygulama Örnekleri}

Oyunun gruplarda kullanımına ve yürütülen süreçlerin planlamalarında nelere dikkat edildiğine ilişkin pek çok araştırma bulunduğundan yukarıda söz edilmişti. Bu kısımda ise oyun terapisinin gruplarda kullanımına ilişkin etkililiği gösterilmiş üç uygulama örnek olması bakımından kısaca tanıtılmıştır.

İlk olarak, yıkıcı davranışların azaltılmasına ve benlik kavramının geliştirilmesine yönelik gelişimsel odaklı olarak planlanmış bir uygulama ele alınmıştır. $\mathrm{Bu}$ uygulama 3. sınıf öğrencilerden altı kişilik gruplarda 10 oturum ve 30-45 dk. olarak yürütülmüştür (Bleck ve Bleck, 1982):

İlk oturumlarda, tanışma etkinliği ve grup kuralları ele alındıktan sonra çocuklar, kendileri için önemli bir şeyi kilden yaparak ve kendileriyle benzer hissettiğini düşündükleri bir hayvanı çizerek duygularını açmış, rol oynayarak duygularını canlandırmıştır. 4. ve 5. oturumda okulda yıkıcı davranışlar sergiledikleri ve öğretmenlerinin kendilerine kızdı̆̆ resmetmiş, resimlerini grupla paylaşmış, üzerine tartışmış daha sonra yıkıcı davranışlar canlandırılmış ve bu davranışların alternatifleri belirlenmiştir. Sonraki iki oturumda çocuklar kendi yaptıkları kuklalarla okulda karşılaşabilecekleri sorunları oyunlaştırmıştır. 8. oturum çiftler halinde birinin gözleri bağlı iken bir yapbozu birlikte tamamlama ve 9. oturum kilden yaptıkları bir hediyeyi partnerlerine hediye etme son oturum ise grup üyelerinin birbirlerine pozitif geribildirimler vermeleri şeklinde kurgulanmıştır.

İkinci örnek 7-12 yaş aralığındaki şiddete tanık olan çocuklara yönelik 12 oturum olarak planlanan sağaltım amaçlı bir uygulamadır. Her oturumda içerik ve süreç amaçları ile uygulanacak etkinlikler olmakla birlikte burada kısaca içerik amaçları ele alınmıştır (Nisivoccia ve Lynn, 2007):

Süreçte dört temel konu yer alır: Duyguların ifadesi, izolasyon ve utanç sorunları, şiddete karşı sorumluluk duygusu geliştirmek ve çatışma çözümü. Grupların hedefleri güvenmeyi, paylaşmayı, arkadaş edinmeyi, duyguları tanımayı ve çatışmalarla başa çıkmayı öğrenmektir. İçerik amaçları ilk üç oturumda; amaç belirleme, kontrat yapma ve güven oluşturma, bilgi ve duygu paylaşımı ile kendini keşfetme, şiddeti tanımlayarak şiddetle baş etmedir. Sonraki üç oturumda şiddeti anlamlandırarak bireyleri nasıl etkileyebileceğini ele alma, şiddet içerikli sözcükleri keşfetme, kendini ifade etme ve izolasyon konularında çalışmaktır. Geri kalan oturumlarda ise bireyleri şiddet içerikli davranışlarından ayrı tutma, sorumluluk geliştirme, duygularını anlama, düşünce, ihtiyaç ve duygular arasındaki farkları belirleyerek önemli olanı tespit etme ve kazanımlar üzerine hepbirlikte konuşma olarak belirlenmiştir.

Üçünücü olarak tanıtılacak uygulama kayıp (yas) yaşamış çocuklara yönelik olarak uygulanan, haftada bir gün ve 1,5 saat süren akran yas destek programıdır. Çocuklar gelişimsel özelliklerine göre 3-5 veya 6-12 ve 13-18 yaş olarak gruplandırılmaktadır (Schuurman ve DeCristofaro, 2007):

Programın dört prensibi vardır. İlki, yasın ölüme karşı doğal bir tepki olmasıdır. Üyeler, ölümün duygusal, davranışsal, fiziksel, bilişsel ve ruhsal etkisi hakkında konuşur ve oynarlar. İkincisi, insanların iyileşme kapasitesine sahip olmasıdır. Profesyonel bir destekle birey iyileşebilir. Üçüncüsü, yas süresi ve yoğunluğu bireye özgüdür prensibidir. Her bireyin yas tutma biçimi farklıdır. Dördüncüsü, yardım ve kabullenme yas sürecine yardımcı olur prensibidir. Programın amaçlar ise şunlardır: Çocukların zarar gören kontrol duygularını geri kazandırmak, evrensellik duygusuyla normal tepkiler verdiğini diğer çocuklardan gözlemleyerek iyileşmek, sosyal destek sağlamak, duyguların önemini göstermek, sözlü ve sözsüz olarak duyguların ifadesini sağlamak, kaybettikleri kişiyi hatırlamaları için bir bağ 
kurmalarına yardımcı olmak, hem kendi ilerlemelerini hem de başklarına aynı konuda verdikleri desteği görmelerini sağlamaktır.

\section{TARTIŞMA, SONUÇ VE ÖNERILER}

Oyun çocukların hayatında bir boş zaman aktivitesi olmaktan ziyade bütün gelişim alanlarını önemli ölçüde etkileyen bir yaşantı olarak ele alınmalıdır. Oyun çocuğun yaşadıklarına ilişkin algılarını sergilediği ve hissettiklerini özgürce ifade edebildiği bir kişisel alan olarak görülmelidir. Oyunun herhangi bir sorun yaşamayan veya sorunlu davranış sergilemeyen çocuğun yaşamındaki gücü bile ele alındığında bu aktiviteye özellikle alan açılması, zaman ayrılması ve imkân tanınması gerektiği anlaşılmaktadır.

Çocuklar gelişimsel özellikleri bakımından belli bir döneme kadar kendilerini kavramlarla ve sözel olarak ifade etmekte güçlük yaşarlar. İşte bu dönemlerde oyun çocuğun kendini ifade etme yolu olarak değerlendirilmelidir. Çünkü oyun çocuğun doğal dilidir (Axline, 1981; Kottman; 2011). Çocukların bu dili kendilerini açmaları için kullanmalarına imkân tanındığında aslında yetişkinlere de çocukların dünyasına girebilme ve yaşantılarının anlamını kavrayabilme olanağı tanınmış olmaktadır. Çocuklar her ne kadar kendilerini sözel olarak ifade edemeseler bile yetişkinlerin kullandıkları kavramların anlamlarını çoğunlukla anlamaktadırlar. O nedenle yetişkinler çocukların oyunundan anladıklarını çocuklara kavramlarla geri yansıtmalıdır. Böylelikle çocuk ve yetişkin arasında daha sağlıklı bir iletişim kurulmaktadır.

Oyun terapisinin geçmişi yaklaşık yüz yılı bulmaktadır ve oyun terapisi uygulamalarının etkili olduğunu gösteren pek çok araştırma mevcuttur. Psikanalitik Kuram'la başlayan oyun terapisi günümüze kadar pek çok kuramsal alt yapıyı kullanarak gittikçe gelişmiş ve bireysel uygulamalardan ailelerin dâhil olduğu uygulamalara oradan da gruplarda uygulanmaya doğru evrilmiştir. Oyun terapsinin gruplarda kullanımı sistemik bakış açısına paralel olarak çocukları grup olarak toplumun bir prototipi içinde ele almakta ve bir nevi gerçek yaşantılarıyla güçlendirmeye çalışmaktadır. Bu yönüyle ele alındığında kendi doğal dilini kullanarak, özgürlük ve özgünlük içinde kendini ifade edebilme imkânı bulan çocuklar aynı zamanda sosyalleşmekte, topluluk içinde uyumlu davranışlar geliştirmekte ve bunlara ek olarak desteklenme duygularını yaşamaktadır.

Böylesi çok yönlü bir sağaltım sürecinin etkililiğine ilişkin yurt dışında yapılmış pek çok araştırma olduğu anlaşılmış ancak Türkiye'de az sayıda araştırmaya rastlanmıştır. Bu konuda Türkiye'de daha fazla araştırma yapılması müdahalenin ülkemizdeki etkililiğine yönelik sonuçların ortaya çıkarılmasını sağlayacaktır. Bu nedenle daha fazla araştırmaya ihtiyaç duyulduğu bertilebilir. Türkiye'de okula devam eden çocuk sayısı 18 milyon 214 bin civarındadır ve bunların yaklaşık 1 milyon 600 bini okul öncesinde, 5 milyon 280 bini ilkokul kademesinde bulunmaktadır (MEB, 2020). Okul psikolojik danışmanlarının sayısı ise Eğitimciler Birliği Sendikası'nın (2018) Eğitime Bakış Raporu'na göre 33 bin civarındadır. Bu sayılar ve birbirlerine olan oranları baz alındığında okul psikolojik danışmanlığ çalışmalarında grupla oyun terapisi müdahalesinin ekonomikliği bağlamında oldukça işlevsel sonuçlar doğurabileceği öngörülmektedir. Benzer olarak doğal afetler ve diğer travmatik yaşantılarda (fiziksel, duygusal, sözel ve cinsel istismar ile ihmallerde) küçük yaş grubundaki çocuklarla terapi yapmanın yöntemi olan oyunun gruplarla yürütülmesi de benzer şekilde işlevsel olmanın yanısıra bir ihtiyaç olarak değerlendirilebilir. Yaşanan travmalara bağlı olarak bazen de bağlantısız şekilde konuşma güçlüğü yaşayan çocuklar için oyun terapisi yapısı gereği konuşma dışında farklı kendini ifade kaynakları sunabildiğinden uygulamaların bu yönüyle de ele alınması önemli görülmektedir. Okulların yanısıra Türkiye'de psikolojik danışmanlık hizmetlerinin yürütüldüğü 250 Rehberlik ve Araştırma Merkezi (RAM) bulunmaktadır (MEB, 2020). RAM'lar okullarda bulunan bütün çocuklardan sorumludur. Ancak öğrenci sayısının fazlalığına göre RAM' ların sayısı göz önünde blundurulduğunda hizmet vermenin zorluğu anlaşılmaktadır. Buna göre RAM'larda grupla oyun terapisi uygulamalarının küçük yaştaki 
danışanlara yönelik kullanılmasının yaygınlaştırılmasının hizmet alanını genişletebileceği düşünülmektedir. Özellikle herhangi bir engel durumu bulunan ve buna bağlı olarak kendilerini ifade etmekte farklı yöntem ve araçlara daha fazla ihtiyaç yaşayabilen çocuklar için böylesi geliştirici aynı zamanda eğlenceli ve alternatifler içeren bir müdahalenin uygulanmasının katkı sağlayacağı düşünülmekte, bu uygulamalar önemli görülmekte ve önerilmektedir.

\section{KAYNAKÇA}

Allan, J. ve Brown, K. (1993). Jungian play therapy in elementary schools. Elementary School Guidance and Counseling, 28, 5-25.

Association for Play Therapy (2019). Play therapy definition. https://www.a4pt.org/page/ClarifyingUseofPT. 03.11.2019 tarihinde ulaşılmıştır.

Apter, S. J. (1977). Applications of ecological theory: Tovvard a community special education model for troubled children. Exceptional Children, 43, 366-373.

Axline, V. (1981). Play therapy. New York: The Ballantine Publishing Group.

Baggerly, J. (2004). The effects of child-centered group play therapy on self-concept, depression, and anxiety of children who are homeless. International Journal of Play Therapy, 13(2), $31-51$.

Baggerly, J. ve Parker, M.(2005). Child-centered group play therapy with african american boys at the elementary school level. Journal of Counseling and Development. 83, 387-396.

Bleck, R.T. ve Bleck, B.L. (1982). The disruptive child's play group. Elementary School Guidance and Counseling, 17(2), 137-141.

Blom, R. (2006). The handbook of gestalt play therapy. (2. Bask1). London: Jessica Kingsley Publishers.

Burghardt, G.M. (2005). The genesis of animal play: Testing the limits. Cambridge, MA: The MIT Press.

Candan, S. (2017). 3-10 yaş arası gelişimsel problemleri olan çocuklarda çocuk merkezli oyun terapisinin etkisinin incelenmesi (Yayınlanmamış yüksek lisans tezi). Atatürk Üniversitesi, Erzurum.

Carmichael, K. (2006b). Play therapy: An introduction. Upper Saddle River, NJ: Pearson.

Cheng, Y. ve Ray, D.C.(2016). Child-centered group play therapy: impact on social-emotional assets of kindergarten children, The Journal for Specialists in Group Work, 41(3), 209-237, doi: 10.1080/01933922.2016.1197350

Chinekesh, A., Kamalian, M., Eltemasi, M., Chinekesh, S. ve Alavi, M. (2014). The effect of group play therapy on social-emotional skills in pre-school children. Global Journal of Health Science, 6, 163-167.

Cohan, S.L., Chavira, D.A. ve Stein, M.B. (2006). Practitioner review: Psychosocial interventions for children with selective mutism: A critical evaluation of the literature from 1990-2005. Journal of Child Psychology and Psychiatry, 47, 1085-1097. doi:10.1111/j.14697610.2006.01662.x

Corey, G. (2015). Psikolojik danışma kuram ve uygulamaları (T. Ergene, Çeviren). Ankara: Mentis Yayıncilık.

Danger, S. (2003). Adaptive doll play: Helping children cope with change. International Journal of Play Therapy, 12(1), 105-116. 
Davenport, B. ve Bourgeois, N. (2008). Play, aggression, the preschool child, and the family: A review of literature to guide empirically informed play therapy with aggressive preschool children. International Journal of Play Therapy, 17(1), 2-23.

Eğitimciler Birliği Sendikası. (2018). Eğitime bakış 2018 izleme ve değerlendirme raporu. Erişim adresi:

https://www.ebs.org.tr/ebs_files/files/yayinlarimiz/EgitimeBakis2018_Izleme_degerlendi rme_raporu.pdf

Else, P. (2009). The value of play. New York: Continuum.

Gil, E. (1991 ). The healing power of play: Working with abused children. New York: Guilford Press.

Glazer, H.R. (2010). Filial play therapy for grieving preschool children. Ed. Charles E. Schaefer (Der.), Play therapy for preschool children içinde (89-107). Washington: American Psychological Association.

Green, E.J. (2008). Reenvisioning jungian analytical play therapy with child sexual assault survivors. International Journal of Play Therapy, 7(2), 102-121. doi: 10.1037/a0012770

Gumaer, J. (1984). Developmental play in small group counseling with disturbed children. The School Counselor, 31(5), 445-453.

Guerney, B.G., Jr., Stollak, G. ve Guerney, 1.F. (1971). The practicing psychologist as educator: an alternative to the medical practitioner model. The Counseling Psychologist, 2 (3), 276282.

Hess. B.A., Post, P. ve Flowers, C. (2005). A follow-up study of kinder training for preschool teachers of children deemed at-risk. International Journal of Play Therapy, 14(1), 103115. doi: $10.1037 / \mathrm{h} 0088898$

Huth-Bocks, A., Schettini, A. ve Shebroe, V. (2001). Group play therapy for preschoolers exposed to domestic violence. Journal of Child and Adolescent Group Therapy, 11(1), 19-33.

Jarareh, J., Mohammadi, A., Nader, M. ve Moosavian, S.A. (2016). The impact of group play therapy on creativity and control of aggression in preschool children. Cogent Psychology, 3(1), 1-9. doi: 10.1080/23311908

Jones, D.K. (2002). Group play therapy with sexually abused preschool children: group behaviors and interventions, Journal For Specialssts In Group Work, 27(4), 377-389. doi: $10.1080 / 714860200$

Kale, A. ve Landreth, G. (1999). Filial therapy with parents of children experiencing learning diffi culties. International Journal of Play Therapy, 8(2), 35-56.

Karcher, M. (2002). The principles and practices of pair counseling: A dyadic developmental play therapy for aggressive, withdrawn, and socially immature youth. International Journal for Play Therapy, 11(2), 121-147.

Klein, M. (1955). The psychoanalytıc play technique. American Journal of Orthopsychiatry. 223237.

Knell, S.M. (2016). Cognitive- behavioral play therapy. Eds. Kevin J. O'Connor, Charles E. Schaefer, Lisa D. Braverman. Handbook of play therapy içinde (119-133). New Jersey: John Wiley \& Sons, Inc.

Knell, S.M. ve Dasar1, M. (2010). Cognitive- behavioral play therapy for preschoolers: integrating play and cognitive-behavioral interventions. Ed. Charles E. Schaefer (Der.), Play therapy for preschool children içinde (157-179). Washington: American Psychological Association. 
Kottman, T. (2011). Play therapy: Basics and beyond. (2. Baskı). Alexandria, VA: American Counseling Association.

Kottman, T. ve Meany-Walen, K. (2016). Partners in play: an Adlerian approach to play therapy. (3. Bask1). VA: American Counseling Association.

Landreth, G.L. (2002). Play therapy: The art of the relationship (2nd ed.). New York: BrunnerRoutledge.

Mastrangelo, S. (2009). Play and the child with autism spectrum disorder: From possibilities to practice. International Journal of Play Therapy, 18(1), 13-30.

Meany-Walen, K.K., Bullis, Q., Kottman, T.ve Taylor, D.D. (2015). Group adlerian play therapy with children with off-task behaviors. The Journal for Specialists in Group Work, 40(3), 294-314. doi: 10.1080/01933922

Millî Eğitim Bakanlığı (2001). Rehberlik ve psikolojik danışma yönetmeliği. Sayı: 24376.

Millî Eğitim Bakanlığı (2020). Millî eğitim istatistikleri örgün eğitim 2019-2020. Erişim adresi: http://sgb.meb.gov.tr/www/icerik_goruntule.php?KNO=396

McMahon, L. (1992). The handbook of play therapy. London: Routledge.

Morrison, M. (2009). Adlerian play therapy with a traumatized boy. Journal of Individual Psychology, 65(1), 57-68.

Mullen, J. (2002). How play therapists understand children through stories of abuse and neglect: A qualitative study. International Journal of Play Therapy, 11(2), 107-119.

Ngamthipwatthana, T., Kiattisirichai, Y., Hosiri, T. ve Manussirivithaya, V. (2018). The Effect of Group Cognitive Behavioral Play Therapy Program on Self-Control among Late Childhood in Foster Care. Siriraj Medical Journal, 70 (6), 507-513. doi:10.14456/smj.2018.82

Nisivoccia, D. ve Lynn, M. (2007). Helping forgotten victims: Using activity groups with children who witness violence. Ed. Nancy Boyd Webb (Der.), Play therapy with children in crisis. Individual, group, and family treatment içinde (294-321). New York, The Guilford Press.

O'Connor, K. (2011). Integrating ecosystemic play therapy and theraplay in the treatment of attachment disorders. Ed. Athena A. Drewes, Sue C. Bratton ve Charles E. Schaefer (Der.), Integrative play therapy içinde (297-325). New Jersey: John Wiley and Sons, Inc.

O'Connor, K. (2016). Ecosystemic play therapy. Eds. Kevin J. O'Connor, Charles E. Schaefer, Lisa D. Braverman. Handbook of play therapy içinde (195-225). New Jersey: John Wiley \& Sons, Inc.

Paone, T. ve Douma, K. (2009). Child-centered play therapy with a seven year-old boy diagnosed with intermittent explosive disorder. International Journal of Play Therapy, 18(1), 31-44.

Porter, M. L., Hernandez-Reif. M. ve Jessee, P.(2009). Play therapy: A review. Early Child Development and Care, 179(8), 1025-1040. doi: 10.1080/03004430701731613

Ray, D., Schottelkorb, A. ve Tsai, M. (2007). Play therapy with children exhibiting symptoms of attention-defi cit hyperactivity disorder. International Journal of Play Therapy, 16(2), 95111.

Ray, D. (2011). Advanced play therapy: Essential conditions, knowledge, and skills for child practice. New York, NY: Taylor and Francis Group.

Ryan, V. (2004). Adapting non-directive play therapy for children with attachment disorder. Clinical Child Psychology and Psychiatry, 9(1), 75-87. 
Schuurman, D.L. ve DeCristofaro, J. (2007). After a parent's death: group, family, and individual therapy to help children. Ed. Nancy Boyd Webb (Der.), Play therapy with children in crisis. Individual, group, and family treatment içinde (173-197). New York, The Guilford Press.

$\mathrm{Su}, \mathrm{S} . \mathrm{H}$. , ve Tsa1, M.H. (2016). Group play therapy with children of new 1mmigrants in taiwan who are exhibiting relationship difficulties. International Journal of Play Therap,. 25 (2), 91-10. doi:10.1037/pla0000014

Sutton-Smith, B. (1997). The ambiguity of play. Cambridge, MA: Harvard University Press.

Sweeney, D.S., Baggerly, J.N. ve Ray, D.C. (2014). Group play therapy: A dynamic Approach. New York, NY: Routledge.

Teke, E. (2019). Oyun terapisiyle bütünleştirilmiş grupla psikolojik danışmanın ilkokul ögrencilerinin sosyal kaygı düzeylerine etkisi (Yayınlanmamış yüksek lisans tezi). Necmettin Erbakan Üniversitesi, Konya.

Tyndall-Lind, A., Landreth, G. ve Giordano, M. (2001). Intensive group play therapy with child witnesses of domestic violence. International Journal of Play Therapy, 10(1), 53-83.

VanFleet, R., Sywulak, A.E. ve Sniscak, C.C. (2010). Child-centered play therapy. New York, The Guilford Press.

Yıldız, C. (2015). Oyun terapisiyle bütünleştirilmiş grup terapisinin çocukların utangaçlık düzeylerine etkisi (Yayınlanmamış yüksek lisans tezi). Beykent Üniversitesi, İstanbul.

\section{EXTENDED ABSTRACT}

Counseling services for children are handled differently from counseling for adults. The most basic requirement that enables this difference to occur can be expressed as the fact that children have different characteristics according to their developmental stages. It is seen that play therapy is widely used in psychological counseling of children today. The reason for this can be considered as the limited verbal expression of their feelings and thoughts in children under the age of twelve. In young children, it often seems difficult to come to the counseling session, sit down and try to explain in words what they experience and feel to a therapist. It can be said that the children in this group do not have enough skills to benefit from the speech-based therapy process due to their developmental characteristics. Instead, children can use toys, art, stories, clay, puppets, etc. in a therapy session. It is stated that it will be more comfortable for them to communicate with the therapist and express themselves by playing roles by using other tools they can play.

Play therapy has a history of about a hundred years and is a way of counseling with children. In play therapy, children express themselves using play which are their natural languages. In addition, they revive their problems by playing games and thus discover emotions that they can not describe. There are many different theoretical approaches to play therapy. For example psychodynamic play therapy, Adlerian play therapy, child-centered play therapy, cognitive behavioral play therapy, filial play therapy etc. However, play therapy practices can be grouped under three headings, which are basically directive, non-directive and family play therapies. The main difference between directive and non-directive approaches is manifested in the way the therapist is involved in the process. Accordingly, in directive play therapy, the therapist is in an interpretative, directing attitude towards the child and during the process. In the second approach, he does not direct the child and does not comment. In the directive approach, the therapist usually determines the game the child will play and the course of the session. The most important feature in these approaches is that the therapist is in the leading position. Examples of this approach include Cognitive-Behavioral Play Therapy and Structured Play Therapy approaches. The most basic example of a non-directive approach is Child-Centered Play Therapy. 
In addition family play therapy focuses on strengthening the child-parent relationship. In this approach, it is aimed to reduce the problematic behaviors of children by developing healthy attachment.

In addition to being applied individually and together with the family, play therapy is also applied in groups made up of children. There are many studies on the effectiveness of the application of play therapy in groups. Group play therapy provides an environment where children can evaluate their own abilities, express themselves in different and alternative ways, and learn how to use their knowledge in a way that they can obtain the maximum advantages appropriate to their capacities. In addition to being a very powerful therapeutically, play therapy with group, it creates an engaging and impressive environment for achieving the goals of therapy according to individual therapy. It can be stated that it is the most effective and economic intervention in terms of creating many new learning and leaving inappropriate attitudes and behaviors. In order to experience reality in a controlled environment, it is important to use real-life tools in group play therapy applications. According to this, among the many real-life play materials, the play therapy bag for use in sessions can include: A family of bendable dolls, a cardboard house with rooms outlined with tape strips, a bottle, plastic plates, a small car, a small airplane, a phone. It is understood that many skills and competencies are developed in children with play therapy intervention with group. For example, it is observed that children who are involved in the group play therapy process have improved in cooperative relationships with their peers and adults and in making friendships, and their interests in classroom activities and academic issues increase.

Nowadays, in addition to individual and family therapies, group therapies are becoming more widespread. In the current literature reviewing to group play therapy abroad, many research has been found. But in Turkey was understood that a limited number of research found.The aim of this study is to consider and introduce play therapy and its application in groups. To this end, play therapy, theoretical approaches in play therapy, and the application of play therapy in groups were examined and discussed. Finally, suggestions on play therapy and the use of play therapy in groups were shared. 